\title{
The entrepreneur's 'resource potential' and the organic square of entrepreneurship: definition and application to the French case
}

\author{
Dimitri Uzunidis, Sophie Boutillier and Blandine Laperche*
}

\author{
* Correspondence: \\ boutilli@univ-littoral.fr \\ Research Unit on Industry and \\ Innovation/ CLERSE-CNRS (UMR \\ 8019), Research Network on \\ Innovation, University Littoral Côte \\ d'Opale, Lille, France
}

\begin{abstract}
The aim of this conceptual paper is to study the origin of the entrepreneur's function. We examine the construction of the entrepreneur's 'resource potential' (the set of knowledge, relations and financial resources gathered together by the entrepreneur) and the role of the socio-economic background in this matter. The 'organic square of entrepreneurship' (resource potential, market, economic organization and public policy) links the individual characteristics of the entrepreneur and the environmental factors to explain entrepreneurship. It is also a tool to study entrepreneurship in different social, economic and political context. We illustrate this role through the analysis of the French case, which reveals the assets and limits of the entrepreneurial context. We particularly show the importance of taking account of the structural characteristics of the productive system in the design of future entrepreneurship policies.

JEL codes: L26; L1; L53

Keywords: Entrepreneur; Resource potential; Organic square of entrepreneurship; French entrepreneur
\end{abstract}

\section{Background}

In a period of crisis, entrepreneurship is considered as a booster for the economic growth through the diffusion of innovations. For Schumpeter, the entrepreneur is indeed the one who disturbs the neo-classical equilibrium by executing new combinations in the means of production and who puts the economy on the path of motion and development (Schumpeter 1939, 1942, 2006). In the current economic context, starting a business is also considered as a solution to face unemployment. In the two cases (innovation and creation of one's own job), entrepreneurship refers to risk taking. As such, for Schumpeter as well as for the many scholars who work on entrepreneurship, being an entrepreneur is not considered as a profession but as a function. In other words, entrepreneurs have a butterfly-like existence.

What is the origin of the entrepreneur's function? Is entrepreneurship a natural gift, as Schumpeter seems to believe? Why does the entrepreneur's function disappear and is not a long-lasting one? To answer these questions, it is important to develop an approach combining economics and sociology, in order to go deeper into the analysis of the social origin of the entrepreneur's function, studying the construction of his 'resource potential, i.e. the set of knowledge, relations and financial resources gathered 
together by the entrepreneur in his environment. This resource potential is not stable and may be increased or reduced, in different economic, political and social contexts (Aldrich 2011; Granovetter 1985; Shane 2003). However, this paper does not try to define the exact ingredients of a 'good' public policy for entrepreneurship. As a matter of fact, since Keynes on the one hand and also the work of the economists of the Public Choice School on the other hand, economists have learnt that the impacts of public policies are not always the expected results (Keynes 1933; Buchanan and Tullock 1962). This paper aims to insist on the way the entrepreneur builds his resource potential and on the role of the socio-economic background in this matter. Notwithstanding his own qualities (smartness and ability to judge), the entrepreneur here is considered as a social actor, influenced by the social, economic and political context.

This conceptual paper builds on the analysis of literature (mainly in economics and sociology) and presents entrepreneurship as based on four pillars that form what we call the 'organic square of entrepreneurship'. The four pillars are the entrepreneur's resource potential, the characteristics of the market, the characteristics of the economic organization and the public policies dedicated to business creation and development. This paper goes deeper in the analysis of the organic square of entrepreneurship and illustrates its role with the analysis of the French case.

The first part of this paper points out the origins of the entrepreneur's function and develops an analysis of the resource potential. The proposed formalization in terms of organic square of entrepreneurship is thus an attempt to explain the temporary character of the entrepreneur's function. In the second part, we analyze as an illustration the current characteristics of the organic square of entrepreneurship in the French context. The organic square of entrepreneurship appears as an interesting tool to emphasize the positive aspects and the limits of the economic and social context that conditions entrepreneurship.

\section{Results and discussion}

The entrepreneur's resource potential and entrepreneurial dynamics The resource potential: the origin of the entrepreneur's function

The entrepreneurial function in a capitalist economy personifies the economic change. This change can take different forms: technological (product or process of production), organization of the enterprise, market organization, etc. To achieve this objective, the entrepreneur mobilizes a set of resources (Penrose 1959). The occupational choice to start and run a business depends on individual abilities and skills but also on the access to social capital that facilitates the entrepreneur's access to information and resources (Granovetter 1985). The entrepreneur, as an individual, finds the needed resources in the environment into which he starts his business. The individual embodies the entrepreneurial function. To explain these interactions between the individual and the environment, we have developed the concept of 'resource potential'. This concept gives the possibility to assess the role played by the social origin, the educational background, the professional experience and the financing sources of new entrants (Boutillier and Uzunidis 2010; Boutillier et al. 2004). All individuals own a set of resources and use their potential to improve their economic situation (to find a job with a good salary, to create an enterprise, to find another professional activity, etc.). The resource potential is not a natural gift but it is the product of a social process and of the opportunities 
and constraints implied by this process. What are the entrepreneurs' social origins? What did they study? Who were their parents? Were they entrepreneurs? Employees? Civil servants? How do they find the funds to start their business? What are their relations?

The resource potential can be analyzed in three parts: (a) knowledge (schooling, secondary education, higher education, further education and professional experience, etc.); (b) financial resources (personal savings, bank loans, venture capital and different forms of public support); (c) relations (family, personal, professional, institutional relations, etc.) (Table 1).

These three parts are interdependent. For example, the knowledge of an individual depends on his education, the professional experience and the resources of the family. Shane and Venkataraman (2000) argue that an individual's idiosyncrasies prior knowledge strongly influences the process of opportunity recognition. The family context (Aldrich and Cliff 2003; Casson 2010) positively or negatively influences the educational choices. While studying, the individual meets new persons, who can become partners and bring knowledge, money and relations. Making up a substantial address book is fundamental because it facilitates the search for money, markets and associates, etc. Many entrepreneurs were born to families of entrepreneurs or create such families. A sizeable proportion of new enterprises are founded by two or more related individual, and specially founded by married couples or cohabitating partners. Regarding the financial resources, Schumpeter focused in priority on the entrepreneur's ability to raise funds, but this ability can be considered as part of a multidimensional ability in which knowledge and relations also have an important role to play.

The capitalist economy needs entrepreneurs to exist. 'Capitalism, then, is by nature a form or a method of economic change and not only never is but never can be stationary' (Schumpeter 1942). The creation of enterprises by individuals is a way to develop new innovations which will feed the economic growth. But, all these new entrepreneurs are not innovators; some of them (or a large part of them) are 'reproducers'. The reproducers create organizations 'whose routines and competencies vary imperceptibly from those of existing organizations in established populations'. The 'innovators' create organizations started 'by entrepreneurs whose routine and competences vary significantly

Table 1 The entrepreneur's resource potential: elements of definition

\begin{tabular}{ll}
\hline Resource potential & Main characteristics \\
\hline Knowledge & Tacit knowledge obtained from the family \\
& Scientific and technical knowledge learned at school \\
& Knowledge obtained through relations \\
& Knowledge obtained through professional experience \\
& Personal savings \\
& Love money: parents, friends, etc. \\
Financial resources & Bank loan \\
& Financial aid from institutions (e.g. public aids) \\
& Seed money from another entrepreneur \\
& Informal relations (family, friends, neighbourhood, colleagues, etc.) \\
& Formal relations (State, banks, other enterprise, research institutes, etc.) \\
\end{tabular}


from those of existing organizations' (Aldrich and Martinez 2001, p. 7). The reproducers even if they are not heroic entrepreneurs (in the sense of Shumpeter), however, contribute to the reproduction of the economic activity on an expanded scale, since they create wealth and jobs.

According the kind of entrepreneur, reproducer or innovator, the level of the resource potential will not be the same. An innovator will often gather a rich and diversified resource potential. Conversely, the resource potential of the reproducer will be weaker. The ability to develop a rich and diversified resource potential not only depends on the willingness (or the gifts) of the individual but also on the context into which he acts. Our approach insists on the analysis of the origin of the entrepreneur's function, trying to add to the notion of 'ability' a social dimension. For example, Schumpeter spoke of the qualities of the entrepreneur, and first of all, his ability to convince the banker. According to us, this ability is not the result of a natural gift (as Schumpeter seemed to believe) but of the association of the other resources that are gathered (knowledge and relations) and of the social, economic and political context. As a matter of fact, the entrepreneurial activity takes place in an environment which 'influences people's willingness to engage in socially productive entrepreneurial activity' (Shane 2003, p. 146), which we call the 'organic square of entrepreneurship', which is studied later. This approach of the resource potential is fed but also differentiated from the current (or more ancient) approaches in terms of social capital, as presented below.

\section{The theoretical roots of the resource potential: an economic approach to social capital}

The concept of social capital officially appeared in human sciences at the beginning of the 1980s. Bourdieu (1980) is one of its main originators. His aim was to go deeper into the analysis of social relations. At the beginning of the 1960s, Becker (1975) defined the concept of 'human capital', considering that all individuals own their knowledge and that they can take the decision to invest in their human capital to increase their merchant value on the labour market. With the concept of social capital, social relations become valuable resources (Boutillier 2006). The concept of social capital is the foundation of the concept of resource potential. However, in the economic and sociological literature, social capital is most often defined as a set of social relations. One may consider that social relations are only a part of the resources that individuals can invest in to find a job, start a business, etc.

Capitalizing one's own knowledge At the beginning of the 1960s, the concept of human capital became essential, in the theory as well as in economic facts. Enterprises and notably big ones needed more and more skilled employees due to the development of the service industry and the clearer separation between design and manufacturing, the affirmation of full employment, the development of the educational system, the continuous technical progress and the resulting automation of industrial work.

This theoretical breakthrough was fundamentally initiated by Becker in the 1960s. Smith did precede him in this analysis, putting a lot of emphasis on the necessary development of education. But the true precursors of human capital are certainly Schulz (1959) and Denison (1962). The quality of human resources, the investment in education, the information of individuals and knowledge are production factors. Becker's human capital is different from physical capital or financial capital because the knowledge 
and know-how acquired by an individual during his training are embedded into him. The employer can take advantage of this knowledge if the employee keeps on working in his enterprise. Employers do not have a property right on their employees.

However, the human capital is a capital and as such the theory of capital can be applied to it, adapting it and putting forward some specific properties: human capital can be accumulated. All individuals may increase the number of years dedicated to their formation, normally through a quasi-indefinite process. Marginal returns of investment in education are decreasing: along the life cycle, the accumulation of human capital follows a decreasing trend. As years go by, economic agents dedicate less time to training, all the more so as job perspectives become less numerous. The human capital return decreases with age: the integration of human capital in the individual limits his investment capacity. He is dependent on his physical and intellectual capacities. Moreover, an individual may accumulate human capital, without any positive result (added value on the labour market); human capital is both a private and a public good as an educated population is also more productive ( $c f$. GDP growth, Lucas 1988).

The theory of human capital therefore presents similarities with the one of capital. The individual invests in himself, as the capitalist invests in his enterprise: the first one is incorporated in the individual, but the capital remains exterior to the entrepreneur who invests it. The law of decreasing marginal returns applies to human and physical capital alike.

Capitalizing one's social relations Since the early 1990s, various works have been conducted by American sociologists (Putnam 2000; Coleman 1988, 1990) in this direction. Social relations are considered as a resource which can be capitalized by individuals. In order to improve their economic welfare, individuals use their social relations which are regarded as an individual and a collective good. According to those authors, the characteristics of social capital are similar to those of physical capital: decreasing returns, decreasing marginal productivity, etc.

Bourdieu (1980) defined the concept of social capital in an analysis of social stratification. Differences in terms of revenues are not the only criterion of differentiation between social classes. For equal revenues, social behaviours and notably cultural ones can be very different. This social capital is a means to gain access to jobs, funding, etc., and the individuals belonging to dominant social classes are those who benefit from a wide network of social relations. Bourdieu defines social capital as the sum of actual or potential resources which are linked to the more or less institutionalised network of interacquaintance and inter-recognition relations possessed by an individual. Every individual is endowed with a social capital, but the latter is not a natural gift but the result of a strategy. Consciously or not, individuals invest to increase their social capital, this one depending on other forms of capital: economic capital, cultural and symbolic one. A high economic or cultural capital facilitates the formation of a social capital. In addition, a high social capital is also a means to increase the economic capital of individuals.

Long before Bourdieu, other sociologists drew attention to the potential wealth that constitutes a network of social relations. Weber (1964) showed the link there was in the USA at the beginning of the twentieth century between the adherence to a religious community and success in business. In 1963, Macaulay (1963) published the result of a study conducted in the USA on transactions between firms, which are very often 
agreed without contracts or in inaccurate legal conditions. Entrepreneurs are often reluctant to formalities which may question trust. For American sociologists who studied the concept at the end of the 1980s, social capital can also be considered as a network of various relations enabling the individual to improve his social insertion. Subtle links between social capital and human capital are also established.

The issue of social capital is only apparently simple (Gasse et al. 2004). It is, as a matter of fact, possible to find as many definitions as there are authors who draw attention to it. Coleman $(1988,1990)$ describes the social capital as a resource incorporated in inter-individual relations. The resources drawn from social capital are privately appropriated and have certain similarities with externalities generated by the functioning of the market. Social capital is productive, just as human capital, and contributes to the increase of welfare. Putnam (2000) defines social capital as the network and reciprocal norms which are associated to it. Social capital has a given value for the individuals who are part of the network. Burt (1995) stressed the role of social networks in the evolution of carriers, studying the promotion of executives in a big technological firm.

In a nutshell, those approaches in terms of human capital and social capital are interesting in that they question the pure rationality of individuals, putting them right in the middle of society (notably the role of family and state is clear) or in the 'strategic group' (Porter 1980) they have chosen: 'Economic action does not take place in a vacuum; rather it is embedded in networks of social relationships' (Minniti 2005, p. 4). In the management literature, the role of social relations and of networks is more and more used to explain the entrepreneurs' success (Sammut 1998; Davidsson and Honig 2003; Suire 2004; Marchesnay 2003; Chabaud and Ngijol 2005, Minniti 2005). But these approaches seem too simplistic because they remain largely focused on the individual, with very few references to the economic, social and political context in which he acts.

Our analysis based on the resource potential can thus be considered as a further step in the social analysis of the requisites for an entrepreneur's success.

\section{The organic square of entrepreneurship}

The resource potential is not a natural gift and is built by a conscious (or unconscious) strategy, linked to the economic, political and social context in which the entrepreneur operates. Moreover this potential is not stable. It can be increased, as explained by the abovementioned American sociologist, but it can also decrease in some special cases or contexts. For example, a bankruptcy in Europe is very badly perceived and may be a case for drastic reduction in the resource potential; in another context, it may not change anything or even be regarded as an entrepreneurial attempt, which has to be followed by other attempts. In the same vein, public policies may help to increase an entrepreneur's resource potential or cause its decrease (support to business creation, taxes in connection with the creation of the enterprise, etc.). The economic organization (regulations, financial system, place of large enterprises and level of technical and knowledge development) and the market (supply and demand) may have the same positive and negative results on the resource potential of the entrepreneur and more globally on entrepreneurship. The formalization in the terms organic square of entrepreneurship is thus an attempt to explain why the entrepreneur's function is not a long-lasting and stable one. Being an entrepreneur (innovator or reproducer) is not a profession but a function which stops when the entrepreneur does not combine 
productive resources anymore: the social, economic and political context may cause the appearance or the disappearance of the entrepreneur.

As a matter of fact, the entrepreneur's dynamism and qualities cannot explain per se the creation and success of small enterprises. This is the reason why a more systematic analysis of the key factors of entrepreneurship in today's economy may be proposed. Four major factors affect this: public policies, economic organization (the importance of large corporations, the nature of the financial system and the level of development of knowledge), and the state of supply and demand which contribute to the building of the resource potential. The interdependence between these factors allows us to analyze them through an organic square of entrepreneurship (Figure 1).

What is the rationale of the 'organic paradigm of entrepreneurship' and how to explain the choice of the incentive factors proposed here? To answer these questions, it is necessary to focus on the key factors of success of small businesses. Shane (Shane 2003) for example makes a synthesis between the Schumpeterian entrepreneur (who is an innovator) and Kirzner's entrepreneur (who has to be well informed to catch the market opportunities; Kirzner 1973, 1985). Shane defines the relevant environmental factors (institutional, political and socio-cultural) which may help the entrepreneur to innovate. However, he does not make reference to the entrepreneur's own resource potential. Many other studies conducted by specialists in management sciences have demonstrated that the creation and durability of small enterprises depend on the entrepreneur's ability to take into account the existing links between different internal factors (organization, financial resources and activity) and external ones (the different levels of the environment) (Sammut 1998; Marchesnay 2003). These approaches are more centred on the individual. Our analysis thus links the two approaches, focused on the entrepreneur and on the environmental factors.

This entrepreneurial success results firstly from the variety and abundance of the resource potential which entrepreneurs have built. The composition of this potential depends on external factors and on the entrant him/herself. In particular, public support (direct or indirect) to the creation of new enterprises usually determines the financial resources entrepreneurs can have access to in order to set up or develop their business. The economic organization has several dimensions and different effects. The general level of development of knowledge influences the knowledge gathered by entrepreneurs

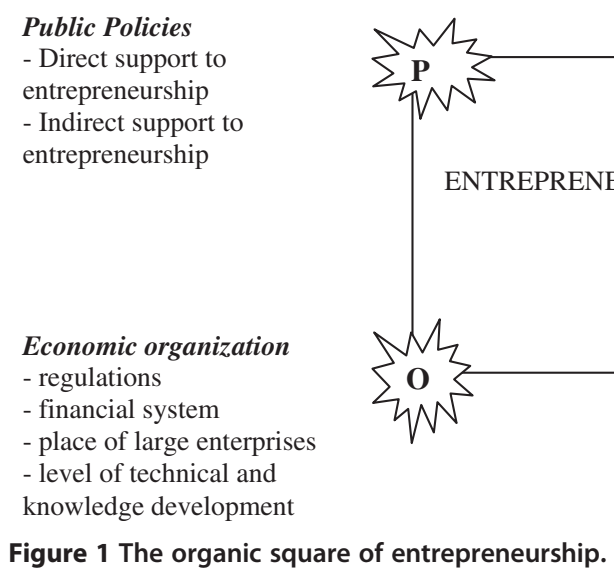

Figure 1 The organic square of entrepreneurship. 
(through their education and that of their staff, through economic intelligence) and the technological level of their activity. The characteristics of the financial system (possibility or difficulty in being listed on the stock exchange, more or less 'conservative' banks, and the access to venture capital) have an impact on the capacity of the individual to become an entrepreneur and on the development of new businesses. Market concentration and the place of large companies also influence the dynamism of entrepreneurial activities and the kind of activity they have. Finally, the overall economic situation determines the rhythm of new creations and also the types of activities conducted by such businesses (Boutillier et al. 2004).

It is in this organic square of entrepreneurship that the entrepreneur's function lies. This is a temporary function because it stems from the gathering at one moment of some special conditions. According to the context, it is also possible to examine the different types of entrepreneurs, which have different resource potentials - e.g. innovators and reproducers. In the second part, we illustrate the current characteristics of the organic square of entrepreneurship in the French context.

\section{The French organic square of entrepreneurship: characteristics and stakes}

\section{Current trends of entrepreneurship in France}

From the beginning of 2000 to 2012, the total of enterprise births has boomed, which is particularly explained by the creation in 2009 of the status of the self-managed enterprise ${ }^{a}$, which has made easier the creation of a new business. It is also explained by the increase in the number of companies (Figure 2). However, during all the period, while the creation of businesses with one or more employees has remained stable, the number of new businesses without employees has largely increased, notably since 2009, thus corresponding to the creation of the self-managed enterprise status. In 2012, 95\% of the new businesses were created without any employee.

But, entrepreneurship in France is not so dynamic in comparison with other industrialized countries. The Global Entrepreneurship Monitor (GEM 2012) defines early-stage entrepreneurial activity (TEA) as the percentage of working age population both about to start an entrepreneurial activity and that have started one from a maximum of

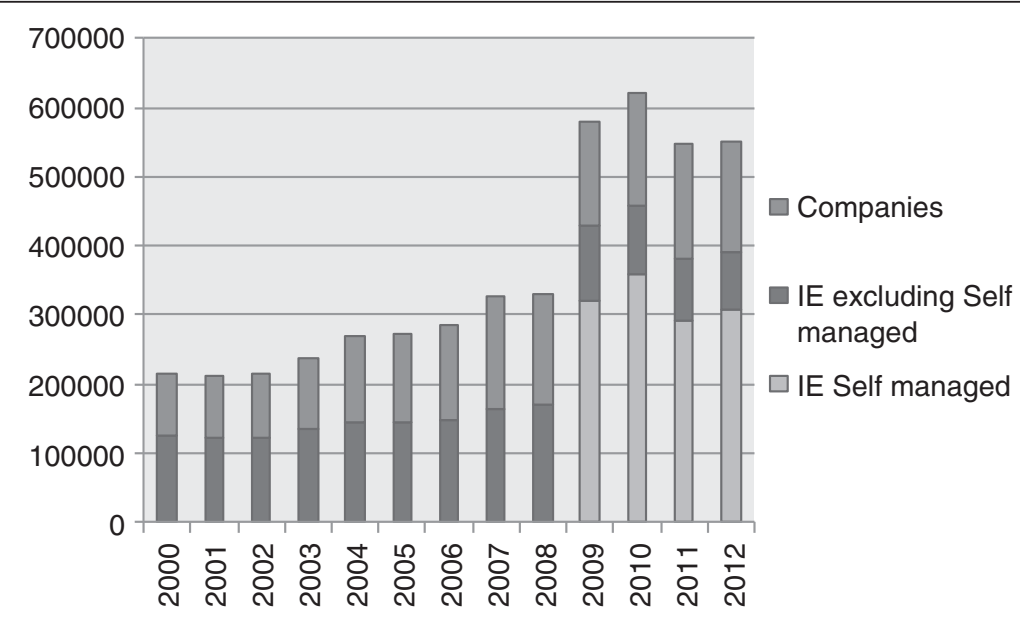

Figure 2 Enterprise births from 2000 to 2012 (Courtesy of National Institute of Statistics and Economic Studies (INSEE), IE: individual enterprise). 
$31 / 2$ years. In 2012 , this indicator only rates $5 \%$ in France, compared to $10 \%$ in Netherlands, $13 \%$ in the UK and in the USA.

Regarding the sectoral distribution, since the beginning of the 2000s, the weight of industry, construction and commerce has decreased to the benefit of services to industry and to households. In 2012, the average age of creators was 38, and women represented $34 \%$ of new individual businesses. Women mostly created in the sectors of education, human health and social work activities (60\% of the creations) and other services to households (57\%), while men created their businesses mostly in construction (97\%) and in information and communication (83\%) (Filatriau and Batto 2013).

The perennity of enterprises has decreased in recent years mainly as a consequence of the economic crisis of 2007-2008 (Barruel 2013). Thus, on the 286,000 enterprises that were created in 2006, 50\% were still in activity 5 years later (compared to $54 \%$ of the enterprises born in 2002) and employment has decreased by $22 \%$. A half of the enterprises created in 2006 are in the sectors of trade and construction, but it is also in these sectors that the perennity is the lowest ( $45 \%$ and $47 \%$, respectively). The third sector of creation of new business is the support of enterprises and in this sector the perennity is much higher (58\%). It is however in the sector of transportation that the perennity is the highest (61\%) even if this sector only accounts for $3 \%$ of the creations.

Apart from the sector, three factors appear to be determining for the perennity of enterprises, which are the legal status of the enterprise, the amount of capital and the level of diploma of the entrepreneur (Barruel 2013). In other words, enterprises are more successful when they have the status of a company compared to an individual enterprise, when the amount of capital invested is higher and when the entrepreneur has a university diploma.

\section{The French Entrepreneur's resource potential}

Each individual has a resource potential which is the result of his socialization. The individual who valorize his potential through the creation of a new business is named an entrepreneur. This function is associated with risk taking and justifies the importance of the resources he holds: financial resources, social relations and knowledge and information resources.

\section{What is the average resource potential of the French entrepreneur's of the 2000s?}

In 2006, more than the three thirds of the enterprises were created with less than 16,000 euros, into which more than one third with less than 4,000 euros (Barruel 2013). So, on average the French entrepreneur starts his new business with few resources. Moreover, entrepreneurs mainly create their business with their own savings, combined with a bank loan and sometimes with the support of the family (love money) (INSEE). A very few benefit from capital venture, which is according to some studies the main reason of the failure of start ups in high-tech sectors in France (Lasch et al. 2005).

Regarding social capital, family plays a major role, but only gives what it owns. The entrepreneur from modest backgrounds benefits from a weak social network, mainly based on family and neighbourhood. The situation is quite the same as in Europe since more than $40 \%$ of young entrepreneurs declared in 2007 that they only benefited from personal and family resources or resources brought by partners (Eurobarometer 2007). In France, an individual is three times more likely to be an entrepreneur if his (or her) 
father or his (or her) mother was an entrepreneur, too. But we notice important differences according to gender: for male entrepreneurs, $50 \%$ of them had a father or a mother who was an entrepreneur, but for female entrepreneur, the percentage falls to $25 \%$ (Cornuau 2008).

The average level of education of entrepreneurs is quite low but is however increasing. The larger part of creators in France, as in Europe, have a secondary level of education (in 2010, 39\% of male creators had a diploma superior to A levels, and 51\% of women entrepreneurs) (INSEE). Most creators also had a professional activity before starting their new business. A quarter of the entrepreneurs that created their business in 2006 had already created one or several enterprises in the past (APCE 2010). The entrepreneurs with the highest degrees are creating businesses in high-tech sectors but in France as in Europe, high-tech entrepreneurship remains undeveloped (Bernasconi and Degroof 2012).

Entrepreneurship culture is considered as not very widespread in France. Historically, the image of the (small) entrepreneur in France has been negative and ambiguous (Marchesnay 2008; Zalc 2012). But recent studies show that the situation on this point is moving (Dhont-Peltrault and Llense 2012a). The authors state that French people consider entrepreneurship positively, are more and more willing to be autonomous and are aware of economic opportunities. However, they lack of confidence, notably regarding their ability to start a business and the fear of failure. In this study which compares the French situation with the American, the British and the German ones, the French situation is comparable to the British and the German ones.

Entrepreneurship is still not widely taught. According to the survey of the European Commission about entrepreneurship, just under a quarter of respondents in France, as in the rest of Europe as a whole, have taken an entrepreneurship course (Eurobarometer 2012). The French education system does not valorize entrepreneurship enough. The system of 'grandes écoles' is criticized and considered as a system of elite reproduction (Bourdieu 1987; Gumbel 2013). The recent example of HEC (Iselin 2012) is very significative. The objective of the school is to push the development of in vitro start up by students, but the beginnings are very disappointing. The main objective of the students is to find a job in a big enterprise.

To sum up, the resource potential of the French entrepreneur remains weak. A recent typology of French entrepreneurs proposed by the French Commissariat for Strategy and Prospective (Dhont-Peltrault and Llense 2012b) confirms this. Taking account of the past situation of entrepreneurs (wage earner, self-employed, unemployed, and no occupation), their diploma and the reasons why they created an enterprise (to be independent, to earn more money, to create their own job, and to exploit a new idea), they identified four profiles of French entrepreneurs:

- The creators by necessity who are former unemployed people who want to create their own job.

- The creators by adaptation who, due to their low level of diploma, are seeking job and revenue opportunities.

- The creators by opportunity were often wage earners and choose to start a new business to improve their situation. 
- The creators by vocation have a very high level of education and their profession often requires being self-employed.

According to Table 2, nearly $60 \%$ of the total number of creators in 2006 resort to the creation by necessity and adaptation, which mostly correspond to a low resource potential (especially regarding the knowledge capital part of this potential). We may consider that they mostly correspond to the reproducer type of entrepreneur to which we referred above.

\section{The economic and political context: what are the stakes?}

The organic square of entrepreneurship aims to demonstrate the importance of the context for explaining the easiness of business creation and the potential of success of young enterprises. These are not only dependent from the entrepreneur's personality. The resource potential he is able to build largely depends on the economic and social context, shaped by the state of the market, the characteristics of the economic organization, and the conduciveness of public policies.

Regarding the state of the market, France, as well as Europe, is facing a difficult economic situation and has implemented austerity policies that cause a decrease in consumption and investments. While growth domestic product (GDP) grew at a rate of $3.7 \%$ in 2000 , it was only $1,7 \%$ in 2011 , after the major recession of $2009(-3.1 \%)$. In the first quarter 2013, French GDP in volume decreased: $-0.2 \%$ after $-0.2 \%$ in the fourth quarter of 2012 (in 2012, no growth of GDP was recorded: 0.0\%). It is the third decrease in the last four quarters (INSEE). Unemployment is rising and could reach $10.9 \%$ at the end of 2013 according to Organisation for Economic Co-operation and Development (OECD). Paradoxically, entrepreneurship benefits from this situation. As a matter of fact, the number of business creation has increased since the beginning of the 2000s. But as shown in Table 2, new business starters are mainly created out of necessity or adaptation. These reproducers temporarily (due to the importance of the failure rate) reduce the number of unemployed people but cannot be considered as assets to get out of the crisis.

The success of entrepreneurship is also depending on the economic organization, which encompasses the incentives given by the legal environmental regulation, the

Table 2 Typical profiles of entrepreneurs in France

\begin{tabular}{|c|c|c|c|c|}
\hline & \multicolumn{4}{|c|}{ Types of creators } \\
\hline & Necessity & Adaptation & Opportunity & Vocation \\
\hline Percentage of total & 36.2 & 22.2 & 22.1 & 19.4 \\
\hline \multicolumn{5}{|l|}{ Reference point } \\
\hline $\begin{array}{l}\text { Motivation to } \\
\text { start a new business }\end{array}$ & Create his/her own job & Various & $\begin{array}{l}\text { The opportunity to create } \\
\text { his/her own enterprise, to } \\
\text { increase his/her revenues }\end{array}$ & $\begin{array}{l}\text { To develop a } \\
\text { new idea, to } \\
\text { practice his/her } \\
\text { profession }\end{array}$ \\
\hline $\begin{array}{l}\text { Situation just before } \\
\text { the creation }\end{array}$ & Unemployed & Various & Wage earner & $\begin{array}{l}\text { Self-employed/ } \\
\text { entrepreneur }\end{array}$ \\
\hline Level of diploma & $\begin{array}{l}\text { Second cycle of secondary } \\
\text { education/technical diploma } \\
\text { of the first cycle of higher } \\
\text { education }\end{array}$ & No diploma & $\begin{array}{l}\text { Second cycle of } \\
\text { secondary education/ } \\
\text { diploma of the first cycle } \\
\text { of higher education }\end{array}$ & Postgraduate \\
\hline
\end{tabular}

Adapted from Dhont-Peltrault and Llense 2012b, with data from INSEE, SINE Enquiry 2006. 
place given to small and big companies and the incentives given to innovation (financial resources and level of technical and knowledge development). According to Doing Business $2013^{\mathrm{b}}$, France is ranked 34 (over 185 countries) in terms of regulatory environment into which business operate, which is under the regional (OECD high income) average (rank 29). Among the indicators, France has the best rankings in enforcing contracts (8), trading across borders (27) and starting a new business (27). France worst ranks are related to registering property (procedures necessary for a business to purchase property from another business and transfer the property title to the buyer's name, 146), protecting investors (ability of companies to raise the capital they need to grow, innovate, diversify and compete, 83) and getting credit (53) (World Bank and International Finance Corporation 2013). While the start of new businesses has been made easier notably by the status of the self-managed enterprise ${ }^{c}$, the development and the innovative character of small businesses still suffer from some important limitations.

In France, in the market sector (excluding agriculture and finance) 95\% of enterprises are microenterprises employing 19\% of all employees, while only 217 enterprises gather $31 \%$ of the employees and achieve a third of the merchant value added (Beguin et al. 2012). In such a concentrated productive organization, the network relationships between small and big companies are a key to the success and, first of all, to the survival of small companies. The development of such network relationship depends on the ability of small businesses to increase their knowledge capital, that is, the scientific and technical competencies they produce and absorb, in order to become of interest for the big company and integrate their productive value chain (as a sub or co-contractor for example). In the matter of building knowledge capital, small businesses usually record weak results (see Laperche and Liu 2013).

Despite the efforts made by public policies to boost innovation (particularly in small companies) notably through the increase of relationships between academic research and business and the clustering policy (Laperche and Uzunidis 2011), these results are still disappointing. The ratio gross domestic expenditure on research and development (GERD) on GDP has reached 2.26\% in France in 2010 (above the Euro-27 average of $2 \%$ ) but is much lower than Nordic countries (Iceland, Finland, Sweden and Denmark, with all more than 3\%), Japan (3.45\%) and USA (2.79\%) (European Commission 2012) . Enterprises represent $63 \%$ of the French GERD but it is mainly the big enterprises who invest in R\&D (they represent 70\% of the total of enterprises expenditures) are concentrated in a small number of sector: automotive sector, pharmaceutical, aeronautics and space industry (INSEE). In 2012, France ranks 6 in terms of patents filed in Europe, after the USA, Japan, Germany, China and Korea and is not a European leader in most of high-tech sectors.

Innovation in France even appears as a system in a situation of failure (Von Bulow 2012), where notably, at the opposite from the USA, France has not created big innovative companies for the last 40 years. One of the main difficulties is the transfer between Science and the market, where the entrepreneur has a major role to play (Acs et al. 2005; Laperche et al. 2008). French clusters are considered as being too numerous (71 clusters - 'poles de compétitivité' in French - are labelled in 2013; see www. competitivite.gouv.fr), based on fragmented topics and thus the financing resources are sprinkled. The same statement is made for academic research where the too numerous 
universities cannot compete at the international level (only three French universities are part of the top 100 Academic ranking of world universities - Shangai Ranking). Finally, one of the most important limit of the French system of innovation is the inefficiency of the financing system (see notably Doing Business 2013), where venture capital is still under-developed and does not facilitate the development of new (high-tech) companies.

French public policies towards entrepreneurship try to improve the context into which businesses operate and in 2013, 44 proposals have been issued in this aim by the 'Assises of entrepreneurship'. Three main aims are announced: stimulating entrepreneurship and mobilizing the talents, helping enterprises to grow and recognizing risk taking. The main measures that are considered are presented in Table 3.

These measures are dedicated to all kinds of entrepreneurs whatever their profile and the innovative level of their sectors. They are also dedicated to investors, giving them new incentives to invest in start ups. However, according to us, they remain very general and do not sufficiently take account of the structural characteristics of the French productive system, dominated as explained above, by large companies. This productive system is also characterized by rigid laws, preventing or making difficult the creation activities. For example for craft entrepreneurs, the law of 1924 (status of the craftsman) creates barriers to entry in some niche activities in all sectors (low and high valueadded) in which the common point is the specific know-how validated by the law and which are potentially sources of many jobs. Corporations, even if they have new shapes, still exist....

Table 3 Main measures considered by the French public policy to boost entrepreneurship (Assises de l'entrepreneuriat 2013)

\begin{tabular}{|c|c|c|}
\hline $\begin{array}{l}\text { Stimulating entrepreneurship } \\
\text { and mobilizing the talents }\end{array}$ & Helping enterprises to grow & Recognizing risk taking \\
\hline $\begin{array}{l}\text { Developing teaching } \\
\text { entrepreneurship at the secondary } \\
\text { level and in universities }\end{array}$ & $\begin{array}{l}\text { Developing on an experimental } \\
\text { basis 'international houses' in the } \\
\text { United States and Asia to facilitate } \\
\text { the implementation of small and } \\
\text { medium-sized enterprises (SMEs) } \\
\text { abroad }\end{array}$ & $\begin{array}{l}\text { Reform of the securities gains in } \\
\text { the direction of simplification and } \\
\text { attractiveness }\end{array}$ \\
\hline $\begin{array}{l}\text { Creation of a fund for the creation } \\
\text { of businesses in neighbourhoods } \\
\text { with fewer opportunities }\end{array}$ & $\begin{array}{l}\text { Incentives for large companies to } \\
\text { invest in young innovative SMEs, by } \\
\text { opening a right to a tax return on } \\
\text { investment }\end{array}$ & $\begin{array}{l}\text { The will to see boosting of the } \\
\text { stock segment dedicated to SMEs } \\
\text { and intermediate-sized enterprise } \\
\text { (ETI) }\end{array}$ \\
\hline $\begin{array}{l}\text { Creation of a Student Entrepreneur } \\
\text { device, which will allow those who } \\
\text { start a business after their studies } \\
\text { to continue to benefit from } \\
\text { student status }\end{array}$ & $\begin{array}{l}\text { Extension of the scope of eligible } \\
\text { exemptions from social security } \\
\text { status of Young Innovative } \\
\text { Companies (YIC); personnel } \\
\text { expenses allocated to innovation } \\
\text { expenditures }\end{array}$ & $\begin{array}{l}\text { Reform of the French 'Plan } \\
\text { Epargne en Actions' (saving plans } \\
\text { based on shares) with the } \\
\text { revaluation of its ceiling up to } € \\
150000 \text { and the opportunity to } \\
\text { invest } € 75,000 \text { more in SMEs and } \\
\text { ETI }\end{array}$ \\
\hline $\begin{array}{l}\text { Removal of the ' } 040 \text { ' of the file } \\
\text { FIBEN Bank of France to promote } \\
\text { the recovery of entrepreneurs }\end{array}$ & $\begin{array}{l}\text { Creation of a fund for social } \\
\text { innovation of BPI (French public } \\
\text { bank for investment) to facilitate the } \\
\text { development of social enterprises in } \\
\text { France }\end{array}$ & $\begin{array}{l}\text { Establishment of a legal framework } \\
\text { for the development of } \\
\text { participatory finance } \\
\text { ('crowdfunding') in France }\end{array}$ \\
\hline $\begin{array}{l}\text { Creation of an 'entrepreneur visa' } \\
\text { or equivalent to attract foreign } \\
\text { talents in France }\end{array}$ & $\begin{array}{l}\text { Creation of a 'pass digital } \\
\text { entrepreneur', which will improve } \\
\text { the personal support of the } \\
\text { contractor and include a mechanism } \\
\text { for reporting administrative } \\
\text { complexities faced by companies }\end{array}$ & \\
\hline
\end{tabular}


In such a productive system, the entrepreneur is 'socialized', which means that his existence, survival and development are embedded and dependent from the actions, strategies and policies of two main agents: the state (its policy, incentives, etc.) and the large companies which are networked-based and achieve the creation of value through complex value chains encompassing multiple actors. In the R\&D field, firms lead open innovation strategies (Chesbrough 2003) in order to be integrated in the innovative ecosystems (made by universities, innovative start ups and small firms, and other innovative companies). At the production and commercialization steps, they combine their own production and commercialisation capacities with subcontractors and cocontractors.

In such a context, the survival and development of (innovative) entrepreneurship largely depend on network competencies. To be part of a network necessitates development of specific capabilities such as absorbing capacities, new knowledge in specific niches and relationship capabilities. Helping young companies to employ young researchers (who face difficulty to enter into the job market), supporting their creation and protection of new knowledge, and creating specific intermediaries between young start ups and large companies could be some interesting ideas (Geay 2013). These aspects are not taken into account in the recent proposals and would however be needed to facilitate the development of innovative entrepreneurship in France.

\section{Conclusions}

To conclude, explaining the conditions of appearance of entrepreneurs is all the more important as the entrepreneur is in the forefront of the economic scene. The entrepreneur is also at the heart of the political debate, his existence and durability being considered as the reason for economic growth.

In this paper, we have shown that the entrepreneurial function relies on the resources that the individual gathers to combine productive factors. This resource potential (knowledge, financing resources and social relations) is the result of the socialization of the individual and cannot be understood without taking account of the context that creates a pool of production factors into which the entrepreneur may tap. The originality of our paper is thus to link two dimensions that are usually analyzed separately in the literature: the individual characteristics of the entrepreneur and the importance of the social, economic and political environment.

The organic square of entrepreneurship is also an interesting tool to study empirically entrepreneurship and thus to point out the assets and limits of entrepreneurship in a country. Our study in the French context has revealed that the French entrepreneur is mainly a reproducer entrepreneur, benefiting from a quite weak resource potential. Even if French policies try to improve the conditions into which the entrepreneur acts (in terms of regulation, level of knowledge and funding), according to us, they do not sufficiently take into account the specific characteristics of the French productive system. This system is dominated by large companies (historically supported by the State), and small ones have a secondary position in terms of innovation, contribution to the national competiveness, etc. and entrepreneurs still face important (legal, market and informal) barriers to start a new business. In addition to the improvement of the innovative context, boosting innovative entrepreneurs (the ones who are able to put the economy on the path of motion and 
development) would require to increase and reinforce the networked capabilities of young entrepreneurs. This idea, which appears as one the results of our analysis of the organic square of entrepreneurship in France, necessitates to be further developed and this will be the next step of our research.

\section{Methods}

This conceptual paper builds on the analysis of literature (mainly in economics and sociology) on entrepreneurship. Our formalization is illustrated by the presentation of the current characteristics of the organic square of entrepreneurship in the French context.

\section{Endnotes}

${ }^{a}$ According INSEE, the self-managed enterprise status ('auto-entrepreneur' status) applies to natural persons who set up or already possess a sole proprietorship, for the purpose of exercising a commercial or artisanal activity or one of the professions (with the exception of certain activities), as a main or complementary activity, and whose sole proprietorship fulfils the conditions of the micro-enterprise fiscal category and who opt for VAT exemption.

${ }^{\mathrm{b}}$ Doing Business sheds light on how easy or difficult it is for a local entrepreneur to open and run a small to medium-size business when complying with relevant regulations. It measures and tracks changes in regulations affecting ten areas in the life cycle of a business: starting a business, dealing with construction permits, getting electricity, registering property, getting credit, protecting investors, paying taxes, trading across borders, enforcing contracts and resolving insolvency.

${ }^{c}$ This status offers less demanding regulations for starting up the business, as well as a simplified method for calculating and paying social security contributions and income tax. Auto-entrepreneurs benefit from a simplified social scheme, exemption from the requirement of registration with the business register for commercial professionals or the trade register for artisans; however, the autoentrepreneur who creates an artisan activity with main title has to join the RM, exemption from VAT, the option of a simplified tax scheme (payment in discharge of income tax) and exemption from property tax of firms for the first 3 years after establishment of the business.

${ }^{\mathrm{d}}$ Figures For Japan and the USA are from 2008.

Competing interests

The authors declare that they have no competing interests.

\section{Authors' contributions}

SB focused on the analysis of the theories of the entrepreneur. DU particularly studied the resource potential of the entrepreneur and BL worked on the organic square of entrepreneurship. All authors read and approved the final manuscript.

Received: 11 September 2013 Accepted: 11 October 2013

Published: 14 Jan 2014

\section{References}

Acs, ZJ, Audretsch, DB, Braunerhjehm, P, \& Carlsson, B. (2005). The Knowledge Spillover Theory of Entrepreneurship. Bloomington (US): Institute for Development Strategies.

Aldrich, HE. (2011). An evolutionary approach to entrepreneurship. Selected essays by H. E. Aldrich. Cheltenham: Edward Elgar. Aldrich, HE, \& Cliff, JE. (2003). The pervasive effects of family on entrepreneurship: toward a family embeddedness perspective. Journal of Business Venturing, 18, 573-596. 
Aldrich, HE, \& Martinez, MA. (2001). Many are called, but few are chosen: an evolutionary perspective for the study of entrepreneurship. Entrepreneurship: Theory and Practice, 25, 41-56.

APCE (Agence pour la Création d'Entreprise). (2010). Quand les créateurs d'entreprise ont déjà l'expérience de l'entrepreneuriat les " multi-créateurs". Paris: APCE.

Assises de l'entrepreneuriat. (2013). http://www.redressement-productif.gouv.fr/cloture-assises-de-l-entrepreneuriat. Accessed 24 May 2013.

Barruel, F. (2013). Les entreprises créées en 2006: une prénnité plus faible dans la construction. Avril: INSEE Première, no. 1441. Paris: INSEE.

Becker, G. (1975). Human capital. Chicago: University of Chicago Press.

Bernasconi, M, \& Degroof, JJ. (2012). Etat d'urgence pour les jeunes entreprises high tech européennes. Entreprendre \& Innover, 4(16), 5-6.

Bourdieu, P. (1980). Le capital social. Actes de la Recherche en Sciences sociales, 31, 115-132.

Bourdieu, P. (1987). Noblesse d'Etat, grandes écoles et esprit de corps. Paris: Editions de minuit.

Beguin, JM, Hecquet, V, \& Lemasson, J. (2012). Un tissu productif plus concentré qu'il ne semblait. In INSEE Première, no. 1399. mars. Paris: INSEE.

Boutillier, S, \& Uzunidis, D. (2010). The innovative milieu as the driving force of entrepreneurship. In B Laperche, P Sommers,

\& D Uzunidis (Eds.), Innovation networks and clusters: the knowledge backbone (pp. 135-158). Bruxelles: Peter Lang.

Boutillier, S, Laperche, B, \& Uzunidis, D. (2004). Technological innovation or social exclusion. In The "organic paradigm" of creation of new enterprises, The French case. Washington: Society for the Advancement of Socio-Economics. 9-11 July.

Boutillier, S. (2006). The end of capitalism: J. K. Galbraith vs K. Marx and J. A. Schumpeter. In B Laperche, J Galbraith, \& D Uzunidis (Eds.), Innovation, evolution and economic change. New ideas in the Tradition of J.K. Galbraith (pp. 53-71). Cheltenham: Edward Elgar.

Buchanan, JM, \& Tullock, G. (1962). The calculus of consent. Ann Arbor: University of Michigan Press.

Burt, RS. (1995). Le capital social, les trous structuraux et l'entrepreneur. Revue française de sociologie, XXXVL, 36(4), 599-628.

Casson, M. (2010). Entrepreneurship, business culture and the theory of the firm. In ZL Acs \& DB Audretsch (Eds.), Handbook of entrepreneurship research (pp. 249-271). New York: Springer.

Chabaud, D, \& Ngijol, J. (2005). La contribution de la théorie des réseaux sociaux à la reconnaissance des opportunités de marché. Revue internationale des PME, 18, 73-90.

Chesbrough, H. (2003). Open innovation: the new imperative for creation and profiting from technology. Boston: Harvard Business Press.

Coleman, JS. (1988). Social capital in the creation of human capital. American Journal of Sociology, 94, 95-120.

Coleman, JS. (1990). Foundations of social theory. Cambridge: Harvard University Press.

Cornuau, F. (2008). Qui sont les entrepreneurs en France? Et comment les économistes et les statisticiens se représentent-ils ces personnes? Revue Internationale de Psychologie et de Gestion des Comportements Organisationnels, 32, 181-205.

Davidsson, P, \& Honig, B. (2003). The role of social and human capital among nascent entrepreneurs. Journal of Business Venturing, 18, 301-331.

Denison, EF. (1962). The sources of growth in the US. New York: Committee for Economic Development.

Dhont-Peltrault, E, \& Llense, F. (2012a). L'entrepreneuriat en France - Volet 1: mythes et réalités en comparaisons internationales, La note d'analyse, no 296. Paris: Centre d'analyse stratégiques.

Dhont-Peltrault, E, \& Llense, F. (2012b). L'entrepreneuriat en France - Volet 2: comment mieux accompagner la prise de risque des créateurs d'entrepruses? In La note d'analyse, no. 297. Centre d'analyse stratégique.

Eurobarometer. (2007). Entrepreneurship Survey of the EU (25 member states), United States and Norway. http://ec.europa.eu/public_opinion/flash/fl_192_en.pdf. Accessed June 2013.

Eurobarometer. (2012). Entrepreneurship in the EU and beyond, Report. August, http://ec.europa.eu/public_opinion/ flash/fl_354_en.pdf. Accessed June 2013.

European Commission. (2012). http://epp.eurostat.ec.europa.eu/statistics_explained/index.php/R_\%26_D_expenditure. Accessed 23 May 13.

Filatriau, O, \& Batto, V. (2013). En 2012, plus d'immatriculation d'auto-entreprises, moins de sociétés. In INSEE Premières, no. 1433. Paris: INSEE.

Gasse, Y, Diochon, M, \& Menzies, T. (2004). Les entrepreneurs émergents dont l'entreprise est devenue opérationnelle et les autres: comparaisons lors de la conception du projet d'entreprise. Journal of Small Business \& Entrepreneurship, 17, 117-134.

Geay, A. (2013). Garantie, financement, innovation: le rôle d'OSEO auprès des PME. In S Boutillier, F Djellal, \& D Uzunidis (Eds.), Linnovation. Analyser, anticiper, agir (pp. 219-225). Brussels: Peter Lang.

Global Entrepreneurship Monitor. (2012). Global report. http://www.gemconsortium.org /docs/2645/gem-2012-globalreport.

Granovetter, M. (1985). Economic action and social structure: the problem of embeddedness. American Journal of Sociology, 91, 481-510.

Gumbel, P. (2013). Elite academy. Paris: Denoël: Enquête sur la France malade de ses grandes écoles.

Iselin, F. (2012). HEC Start up invitro ou la procréation assistée pour entreprises innovantes. Entreprendre \& Innover, 16, 38-45.

Keynes, JM. (1933). The means to prosperity. London: Macmillan.

Kirzner, I. (1973). Discovery and the capitalist process. Chicago: University of Chicago Press.

Kirzner, I. (1985). Entrepreneurial discovery and the competitive market process: an Austrian approach. The Journal of Economic Literature, 35, 60-85.

Laperche, B, Uzunidis, D, \& von Tunzelmann, NG. (2008). The genesis of innovation. systemic linkages between knowledge and the market. Cheltenham: Edward Elgar. 
Laperche, B, \& Uzunidis, D. (2011). The impacts of reforms on research and innovation in France: direction, planning and coordination. Higher Education Management and Policy, 23(2), 1-20. OECD.

Laperche, B, \& Liu, Z. (2013). Small business and knowledge capital formation in innovation networks: a review of literature. Journal of Innovation and Entrepreneurship. in press.

Lucas, R. (1988). On the mechanics of economic development. Journal of Monetary Economics, 72, 3-42.

Lasch, F, Le Roy, F, \& Yami, S. (2005). Les determinants de la survie et de la croissance des start-up TIC. Revue française de gestion, 155, 37-56.

Macaulay, S. (1963). Non-contractual relations in business: a preliminary study. American Sociological Review, $28,55-67$.

Marchesnay, M. (2003). La petite entreprise: sortir de l'ignorance. Revue française de gestion, 144, 107-118.

Marchesnay, M. (2008). L'entrepreneur: une histoire française. Revue française de gestion, 188-189. 77-95.

Minniti, M. (2005). Entrepreneurship and network externalities. Journal of Economics Behavior \& Organization, $57,1-27$.

Penrose, E. (1959). The theory of the growth of the firm. New York: Wiley.

Porter, M. (1980). Competitive strategy. New York: Free Press.

Putnam, R. (2000). Bowling alone: the collapse and revival of American community. New York: Simon and Schuster.

Sammut, S. (1998). Jeune entreprise. La phase cruciale du démarrage. Paris: L'Harmattan.

Schulz, TW. (1959). Investment in man: an economist's view. The Social Service Review, XXXIII, 33(2), 109-117.

Schumpeter, JA. (1939). Business cycles. New York: Macgraw Hill.

Schumpeter, JA. (1942). Capitalism, socialism and democracy. London: Routlegde.

Schumpeter, JA. (2006). The theory of economic development (1911). New Brunswick: Transaction Publishers.

Shane, S. (2003). A general theory of entrepreneurship. The individual-opportunity nexus. Cheltenham: Edward Elgar.

Shane, S, \& Venkataraman, S. (2000). The promise of entrepreneurship as a field of research. Academy of Management Review, 25, 226-317.

Suire, R. (2004). Des réseaux de l'entrepreneur au ressort créatif: quelles stratégies pour les territoires. Revue internationale des PME, 17, 29-54.

Von Bulow, N. (2012). Linnovation en France: un système en échec, note 1/19. Terra Nova. www.tnova.fr. Accessed June 2013. Weber, M. (1964). L'éthique protestante et l'esprit du capitalisme, (1905). Paris: Plon.

World Bank and International Finance Corporation. (2013). Doing business 2013. France: economy profile.

Zalc, C. (2012). Les petits patrons en France au 20e siècle ou les atouts du flou. Vingtième Siècle, 144, 53-66.

10.1186/2192-5372-3-1

Cite this article as: Uzunidis et al:: The entrepreneur's 'resource potential' and the organic square of entrepreneurship: definition and application to the French case. Journal of Innovation and Entrepreneurship 2014, 3:1

\section{Submit your manuscript to a SpringerOpen ${ }^{\circ}$ journal and benefit from:}

- Convenient online submission

Rigorous peer review

- Immediate publication on acceptance

- Open access: articles freely available online

- High visibility within the field

Retaining the copyright to your article

Submit your next manuscript at $\boldsymbol{\wedge}$ springeropen.com 